\title{
Monitoring of airborne bacteria and aerosols in different wards of hospitals - Particle counting usefulness in investigation of airborne bacteria
}

\author{
Seyed Hamed Mirhoseini', Mahnaz Nikaeen', Hossein Khanahmad², Maryam Hatamzadeh', \\ Akbar Hassanzadeh ${ }^{3}$
}

1 Department of Environmental Health Engineering, School of Health, Isfahan University of Medical Sciences, Isfahan, Iran
2 Department of Genetics and Molecular Biology, School of Medicine, Isfahan University of Medical Sciences, Isfahan, Iran
${ }^{3}$ Department of Statistics and Epidemiology, School of Health, Isfahan University of Medical Sciences, Isfahan, Iran

Mirhoseini SH, Nikaeen M, Khanahmd H, Hatamzadeh M, Hassanzadeh A. Monitoring of airborne bacteria and aerosols in different wards of hospitals: Particle counting usefulness in investigation of airborne bacteria. Ann Agric Environ Med. 2015 ; $22(4)$ : 670-673. doi: $10.5604 / 12321966.1185772$

\begin{abstract}
Introduction and objective. The presence of airborne bacteria in hospital environments is of great concern because of their potential role as a source of hospital-acquired infections (HAl). The aim of this study was the determination and comparison of the concentration of airborne bacteria in different wards of four educational hospitals, and evaluation of whether particle counting could be predictive of airborne bacterial concentration in different wards of a hospital.

Materials and method. The study was performed in an operating theatre (OT), intensive care unit (ICU), surgery ward (SW) and internal medicine (IM) ward of four educational hospitals in Isfahan, Iran. A total of 80 samples were analyzed for the presence of airborne bacteria and particle levels.

Results. The average level of bacteria ranged from 75-1194 CFU/m³. Mean particle levels were higher than class 100,000 cleanrooms in all wards. A significant correlation was observed between the numbers of $1-5 \mu$ m particles and levels of airborne bacteria in operating theatres and ICUs. The results showed that factors which may influence the airborne bacterial level in hospital environments should be properly managed to minimize the risk of HAls especially in operating theaters. Conclusions. Microbial air contamination of hospital settings should be performed by the monitoring of airborne bacteria, but particle counting could be considered as a good operative method for the continuous monitoring of air quality in operating theaters and ICUs where higher risks of infection are suspected.
\end{abstract}

\section{Key words}

airborne bacteria, hospital infection, particle counting

\section{INTRODUCTION}

The incidence of hospital-acquired infections (HAI) by pathogenic or potentially pathogenic bacteria is a serious problem worldwide. There is increasing evidence that some infectious agents are airborne and hospital air could be considered as a potential transmission route of nosocomial infections [1]. The principal pathogenic bacteria, such as Streptococcus pyogenes, Neisseria meningitidis, Corynebacterium diphtheriae and Mycobacterium tuberculosis, are known to be transmitted mainly by airborne droplets from infected people, and they may cause nosocomial infections $[1,2]$. It is estimated that airborne bacteria cause about $10-20 \%$ of endemic nosocomial infections [3]. Hospital indoor air may contain a wide range of pathogenic and non-pathogenic microorganisms which could originate from patients, the staff, visitors, ventilation and air conditioning systems, and outdoors [4]. Although some airborne bacteria in the hospital environment may be harmless to healthy people, they can impact on a vulnerable group of hospitalized patients and cause serious threats to health [5]. Immunocompromised patients could be at a significantly increased risk of airborne bacteria exposure

Address for correspondence: Mahnaz Nikaeen, Department of environmental health engineering, School of Health, Isfahan University of Medical Sciences, Hezar Jerib Avenue, Isfahan, Iran.

E-mail address: nikaeen@hlth.mui.ac.ir

Received: 27 March 2015; accepted: 21 April 2015
[1]. Due to an increase in immunocompromised patients [6], hospitals are now more often facing the problem of HAIs, and airborne bacteria may be a major factor in increasing morbidity and mortality in the patients.

Infection prevention in hospital environments, therefore, is an important issue in terms of both patient outcomes and cost of treatment [7]. Bioaerosol monitoring in indoor hospital environments could be used as an important approach in the prevention of airborne HAIs. In other words, monitoring of airborne microorganisms in hospital settings can provide information about bioaerosol sources, concentration and dispersion, and also could be used as a quality control measure [8]. There are some investigations on bioaerosol concentrations and characterizations in different wards of hospitals, especially operating theatres and intensive care units (ICU). There is, however, few data about the air quality in hospitals in developing and transition countries where factors such as hospital design, deficiency or improper control of high efficiency filtration systems and overcrowding can impact on the presence and concentration of airborne microorganisms. In addition, routine air biomonitoring of hospitals is time-consuming, labour intensive and is valid only for the moment and location of collection [9]. It has been suggested that particle counting could be used as a faster and simpler alternative. However, its value in the prediction of airborne bacteria in various parts of hospital environments has rarely been investigated $[7,9,10]$. 


\section{OBJECTIVES}

The study was designed to determine and compare concentrations of airborne bacteria in different wards of four educational hospitals, and to evaluate whether particle counting could be predictive of airborne bacterial concentration in different wards of a hospital.

\section{MATERIALS AND METHOD}

Sampling locations. The study was performed in four educational hospitals in Isfahan, Iran, during 2014. Air samples were collected at four sites in each hospital, including the operating theatre (OT), intensive care unit (ICU), surgery (SW) and internal medicine (IM) ward. Each area in the hospital was visited five times. Therefore, a total of 80 samples were analyzed for airborne bacteria and particle levels. Air sampling and particle counting were performed at a height of $1.5 \mathrm{~m}$ above ground level to simulate the breathing zone.

Airborne bacteria. Airborne bacteria were drawn into all glass impingers (AGI), which contained $20 \mathrm{ml}$ of phosphate buffer, using portable pumps at a flow rate of $12.5 \mathrm{~L} / \mathrm{min}$. Sampling time was adjusted in the range of $180-240 \mathrm{~min}$ to obtain sufficient colony numbers.

All samples were transferred to the laboratory in an insulated box with cooling packs, and were processed immediately after arrival at the laboratory.

Aliquots of each impinger collection medium were plated onto duplicate tryptic soy agar (TSA) and incubated at $30^{\circ} \mathrm{C}$ for $2-3$ days. Colonies growing on both media were enumerated and calculated as colony-forming units per cubic meter $\left(\mathrm{CFU} / \mathrm{m}^{3}\right)$.

Particle counting. An optical particle counter (GRIMM 1.109 dust monitor, Germany) was used to measure the number-size distribution of aerosols. Particle numbers were classified in six size ranges (less than $0.5 \mu \mathrm{m}),(0.5-0.9 \mu \mathrm{m})$, $(1.0-2.9 \mu \mathrm{m}),(3-4.9 \mu \mathrm{m}),(5-9.9 \mu \mathrm{m})$ and $\geq 10 \mu \mathrm{m}$ and the values of particles were calculated per 1 cubic meter. However, as the threshold values were reported per cubic foot (as ' 10,000 ', ' 100,000 '), the values per 1 cubic foot are shown in parentheses.

Measurement of humidity and temperature. During sampling, temperature and relative humidity were also recorded by use of a portable weather station (Kimo) at each sampling site.

Statistical analysis. Statistical analysis was conducted with SPSS 20.0. Kolmogorov-Smirnov test for normality was performed for the use of parametric or non-parametric tests. The Kruskal-Wallis test was used to compare the concentration differences of airborne bacteria among the sampling sites. The relationships between particle numbers and airborne bacterial concentrations were examined using the non-parametric Spearman's rank correlation method. All probability $(\mathrm{P})$ values smaller than 0.05 were considered statistically significant for all analyses.

\section{RESULTS AND DISCUSSION}

Hospital environments are complex settings where various factors, such as hospital design, ventilation system, temperature, relative humidity, population density and disinfection methods, can influence the concentration of airborne bacteria. Table 1 presents the average airborne bacterial levels in different wards of the investigated hospitals. Airborne bacteria were isolated from different parts of the hospitals at a level ranged from $30-3,250 \mathrm{CFU} / \mathrm{m}^{3}$. Fluctuations occurred in airborne bacterial concentrations in hospitals and in different wards (Tab. 1). However, significant differences were not found among the four hospitals. Generally, the mean bacterial levels in the investigated hospitals were lower than mean levels recorded in five hospital wards in the United Arab Emirates [11], and a hospital ward in a tropical setting situated in West Chennai, India [12]. However, the mean bacterial levels determined in this study were comparable with levels reported in Silesian hospitals in Poland [1], and mean monthly concentrations of airborne bacteria in a ward hospital in Poland [13]. The highest of total mean level of both particle count and airborne bacteria were observed in surgical wards, (Tab. 1,2). However, there was no significant difference in airborne bacteria among the four investigated areas, including the surgical ward, internal medicine, operation theatre and ICU. On the other hand, the lowest total level of airborne bacteria was found in ICUs, while particle counts in operating theatres were lower than ICUs (Tab. 1, 2). According to a study by Li and Hou, the bacterial concentrations in hospital ICU varied over a wide range $\left(1-423 \mathrm{CFU} / \mathrm{m}^{3}\right)$ [8]. A possible explanation for the lowest total level of airborne bacteria in the ICU would be the special condition of the ward as a restricted area, and also the presence of high ventilation rate systems [2]. The bacterial levels determined in operating theatres ranged from $45-1,733 \mathrm{CFU} / \mathrm{m}^{3}$, with a mean level of $396 \mathrm{CFU} / \mathrm{m}^{3}$ (Tab. 1 ) which was higher than those previously reported in other studies $[1,8,9,10,14]$.

Table 1. Average level of airborne bacteria $\left(\mathrm{CFU} / \mathrm{m}^{3}\right)$ in different wards of hospitals

\begin{tabular}{cccccc}
\hline Hospital & \multicolumn{5}{c}{ Sampling Location } \\
\hline 1 & OT & ICU & SW & IM & Total \\
\hline 2 & 102 & 130 & 337 & 117 & 171 \\
\hline 3 & 673 & 75 & 84 & 88 & 230 \\
\hline 4 & 168 & 446 & 1194 & 944 & 688 \\
\hline Total & 642 & 239 & 532 & 948 & 590 \\
\hline
\end{tabular}

However, differences in airborne bacterial levels between studies may be due to sampling or culturing method and to environmental quality. Some countries have set airborne bacterial limits for operating theatres [15]. Microbial air contamination of operating theatres during surgical procedures could be a risk factor for surgical site infection through settling of airborne bacteria $[10,16]$. The presented results show higher airborne bacterial concentrations than the limits. Various factors influence the airborne bacteria during surgical procedures. High concentration of airborne bacteria in the current study may be related to filtration systems efficiency, operating team numbers, and their activity 
Table 2. Mean particle counts by size in different wards

\begin{tabular}{|c|c|c|c|c|c|c|}
\hline \multirow[t]{2}{*}{ Location } & \multicolumn{6}{|c|}{ Particulate count $/ \mathrm{m}^{3}\left(/ \mathrm{ft}^{3}\right)$} \\
\hline & $<0.5 \mu \mathrm{m}$ & $0.5-0.9 \mu \mathrm{m}$ & $1-2.9 \mu \mathrm{m}$ & $3-4.9 \mu \mathrm{m}$ & $5-9.9 \mu \mathrm{m}$ & $\geq 10 \mu \mathrm{m}$ \\
\hline OT & $\begin{array}{r}32326341 \\
(915385)\end{array}$ & $\begin{array}{l}4211993 \\
(119271)\end{array}$ & $\begin{array}{l}833563 \\
(23604)\end{array}$ & $\begin{array}{c}163082 \\
(4618)\end{array}$ & $\begin{array}{l}40965 \\
(1160)\end{array}$ & $\begin{array}{l}4732 \\
(134)\end{array}$ \\
\hline ICU & $\begin{array}{l}40013278 \\
(1133056)\end{array}$ & $\begin{array}{l}5041989 \\
(142774)\end{array}$ & $\begin{array}{l}922732 \\
(26129)\end{array}$ & $\begin{array}{c}175018 \\
(4956)\end{array}$ & $\begin{array}{l}41636 \\
(1179)\end{array}$ & $\begin{array}{l}7275 \\
(206)\end{array}$ \\
\hline SW & $\begin{array}{l}43174771 \\
(1222580)\end{array}$ & $\begin{array}{l}6212099 \\
(175908)\end{array}$ & $\begin{array}{c}1464068 \\
(41458)\end{array}$ & $\begin{array}{c}305188 \\
(8642)\end{array}$ & $\begin{array}{l}90793 \\
(2571)\end{array}$ & $\begin{array}{c}15185 \\
(430)\end{array}$ \\
\hline IM & $\begin{array}{c}32507116 \\
(920504)\end{array}$ & $\begin{array}{l}4922379 \\
(139387)\end{array}$ & $\begin{array}{l}957199 \\
(27105)\end{array}$ & $\begin{array}{c}273334 \\
(7740)\end{array}$ & $\begin{array}{l}94749 \\
(2683)\end{array}$ & $\begin{array}{l}11336 \\
(321)\end{array}$ \\
\hline
\end{tabular}

in operating theaters, and surgery operation. Pankhurst et al. indicated that the presence of people within the operating theatre had the greatest impact on both airborne bacteria and particle counts, resulting in an increase in both cases [17]. Nevertheless, the lowest mean particle numbers were measured in operating theatres (Tab. 2). Some studies have shown that the particle peaks are not associated with the peak of airborne bacteria, due to the presence of non-bacteria carrying particles $[9,16]$. The mean particle counts (particle size $\geq 0.5 \mu \mathrm{m})$ were above maximum level for class 100,000 cleanroom [15] (Tab. 2). Particle counting for operating theatres were somewhat higher than levels in class 100,000 of cleanroom. Among the 20 analyzed samples of operating theatres, only $11(55 \%)$ particle samples were below the maximum level for class 100,000 cleanroom. Ortiz et al. reported that bacterial concentrations in operating theatres were lower than levels in class 100,000 cleanroom, but higher than class 100 [14]. According to the study by Li and Hou, most particle counts were higher than the designated 10,000/ $\mathrm{ft}^{3}$ level in an operating theatre [8]. In other wards of the hospitals surveyed (internal medicine and surgical ward), the average particle concentration exceed the European ISO 14644 standard limits [15] for ISO 8 cleanroom.

In addition, the particle count of ICUs showed that $60 \%$ $(12 / 20)$ of the samples had a particle level $(\geq 0.5 \mu \mathrm{m})$ higher than $100,000 / \mathrm{ft}^{3}$ in class 100,000 cleanroom.

In order to identify the possible association between the different sized particles and airborne bacterial concentration in various sampling sites of the hospitals, a correlation analysis was performed (Tab. 3). Although there was no relationship among class level and airborne bacterial concentrations, significant correlations were observed between airborne bacterial concentrations and particle size of $1-5 \mu \mathrm{m}$ in operating theaters and ICUs (Tab. 3). Stocks et al. found a correlation between the number of particles $\geq 10 \mu \mathrm{m}$ with the number of CFUs in operating theatres [7]. Seal and Clarck also demonstrated a significant correlation between particles sized 5-7 $\mu \mathrm{m}$ and microbial contamination during surgical operations performed in an ultra-clean theatre [18]. This relationship between the numbers of particles 1-5 $\mu \mathrm{m}$ and airborne bacterial concentrations supports the notion that particle counting may act as a surrogate measure of airborne bacteria in operating theatres and ICUs. However, the applicability of particle counting in the monitoring of airborne bacteria is controversial. Scaltriti et al. and Landrin et al. observed no correlation between particle counts and microbial load in operating theaters [9, 10]. They recommended that there is no reason to replace microbiological sampling with particle counting for routine assessment of microbiological contamination. The results
Table 3. Spearman's correlation coefficient between bacterial levels and different size of particles in different wards

\begin{tabular}{lllll}
\hline Particle size & OT & ICU & IM & SW \\
\hline$<0.5 \mu \mathrm{m}$ & 0.438 & $0.706^{*}$ & 0.035 & 0.490 \\
\hline $0.5-1 \mu \mathrm{m}$ & 0.504 & 0.448 & -0.259 & $0.671^{*}$ \\
\hline $1-5 \mu \mathrm{m}$ & $0.655^{*}$ & $0.762^{* *}$ & -0.028 & 0.154 \\
\hline$\geq 5 \mu \mathrm{m}$ & 0.27 & 0.371 & 0.007 & 0.266 \\
\hline
\end{tabular}

* Correlation significant at the 0.05 level ( 2 tailed)

of the current study also revealed no correlation in internal medicine wards. In addition, there was a different correlation for surgical wards (correlation between particles $0.5-1 \mu \mathrm{m}$ and airborne bacteria). Overall, it seems that particle counting as a rapid and real-time monitoring technique can be used in some aspects of HAIs control, particularly where higher rates of infection are suspected [17]. However, more studies are required to explore the usefulness of particle counting as a surrogate measure of airborne bacteria monitoring in hospital settings.

Temperature and relative humidity are important environmental factors that affect bioaerosols survival. The airborne bacterial concentration in hospital environments was significantly correlated to relative humidity, but not to temperature (Tab. 4). Similarly, Obbard and Fang reported a significant correlation between airborne bacteria and relative humidity, but not temperature in wards of a Singapore hospital [19]. However, some studies found no significant relationship between airborne bacteria and environmental parameters in hospital wards $[13,20]$.

Table 4. Correlation analysis results between meteorological conditions and airborne bacterial levels

\begin{tabular}{lccc}
\hline & Bacteria & Temperature & Relative humidity \\
\hline Bacteria & 1 & & \\
\hline Temperature & 0.019 & 1 & \\
\hline Relative humidity & $0.328^{*}$ & 0.182 & 1 \\
\hline
\end{tabular}

* Correlation significant at the 0.05 level ( 2 tailed)

\section{CONCLUSION}

This study analyzed the levels of airborne bacteria and particle counts in various wards of four educational hospitals in Isfahan, Iran. Airborne bacteria were isolated from different wards of the hospitals at a level ranging from $30-3,250 \mathrm{CFU} / \mathrm{m}^{3}$. The results showed that airborne bacterial levels in operating theatres were higher than reasonable and acceptable limits. Evaluation of particle counts in operating theatres and ICUs showed that most of the particle levels were higher than the designated concentration in class 100,000 cleanrooms. Therefore, the factors which may influence the airborne bacterial level in hospital settings should be properly managed to minimize the risk of HAIs, especially in operating theatres. A correlation was also observed between particle counting (particles sized 1-5 $\mu \mathrm{m}$ ) and airborne bacterial concentration in operating theatres and ICUs. This suggests that the combining of particle counting as a real-time monitoring method with routine evaluation of microbial air contamination in hospital settings could provide instantaneous information about rapid variations of air quality in some aspects of infection control. 


\section{Acknowledgement}

The research was conducted with funding from the Vice Chancellery for Research of Isfahan University of Medical Sciences (Research Project \# 392542) as a part of a PhD dissertation thesis. The authors wish to extend their thanks to the hospital personnel for their assistance during the study.

\section{REFERENCES}

1. Pastuszka JS, Marchwiñska-Wyrwal E, Wlazol A. Bacterial Aerosol in Silesian Hospitals: Preliminary Results. Pol J Environ Stud. 2005; 14: $883-890$

2. Kim KY, Kim YS, Kim D. Distribution characteristics of airborne bacteria and fungi in the general hospitals of Korea. Ind Health. 2010; 48: $236-243$

3. Fernstrom A, Goldblatt M. Aerobiology and Its Role in the Transmission of Infectious Diseases. J Pathogens. 2013; doi: 10.1155/2013/493960.

4. Cole EC, Cook CE. Characterization of infectious aerosols in health care facilities: an aid to effective engineering controls and preventive strategies. Am J Infect Control. 1998; 26: 453-464.

5. Knibbs LD, Morawska L, Bell SC, Grzybowski P. Room ventilation and the risk of airborne infection transmission in 3 health care settings within a large teaching hospital. Am J Infect Control. 2011;39: 866-872.

6. Lockhart SR, Diekema DJ, Pfaller MA. The epidemiology of fungal infections. In: Anaissie EJ, McGinnis MR, Pfaller MA (eds) Clinica Mycology 2rd edn. Churchill Livingstone, Edinburgh 2009.p. 1-14.

7. Stocks GW, Self SD, Thompson B, Adame XA, O’Connor DP. Predicting bacterial populations based on airborne particulates: A study performed in nonlaminar flow operating rooms during joint arthroplasty surgery. Am J Infect Control. 2010; 38: 199-204.

8. Li CS, Hou PA. Bioaerosol characteristics in hospital clean rooms. Sci Total Environ. 2003; 15: 169-176.
9. Scaltriti S, Cencetti S, Rovesti S, Marchesi I, Bargellini A, Borella P. Risk factors for particulate and microbial contamination of air in operating theatres. J Hosp Infect. 2007; 66: 320-326.

10. Landrin A, Bissery A, Kac G. Monitoring air sampling in operating theatres: can particle counting replace microbiological sampling? J Hosp Infect. 2005; 61: 27-29.

11. Jaffal AA, Nsanze H, Bener A, Ameen AS, Banat IM, El Mogheth AA. Hospital airborne microbial pollution in a desert country. Environ Int. 1997; 23: 167-172.

12. Sudharsanam S, Swaminathan S, Ramalingam A, Thangavel G, Annamalai R, Steinberg R, Balakrishnan K, Srikanth P. Characterization of indoor bioaerosols from a hospital ward in a tropical setting. Afr Health Sci. 2012; 12: 217-225.

13. Augustowska M, Dutkiewicz J. Variability of airborne microflora in a hospital ward within a period of one year. Ann Agr Environ Med. 2006; 13: 99-106.

14. Ortiz G, Yague G, Segovia M, Catalan V. A study of air microbe levels in different areas of a hospital. Curr Microbiol.2009; 59: 53-58.

15. Dharan S, Pittet D. Environmental controls in operating theatres. J Hosp Infect. 2002; 51: 79-84.

16. Verkkala K, Eklund A, Ojajarvi J, Tiittanen L, Hoborn J, Makela P. The conventionally ventilated operating theatre and air contamination control during cardiac surgery--bacteriological and particulate matter control garment options for low level contamination. Eur J Cardiothorac. 1998; 14: 206-10.

17. Pankhurst LJ, Taylor J, Cloutman-Green EA, Hartley JC, Lai KM. Can Clean-Room Particle Counters be Used as an Infection Control Tool in Hospital Operating Theatres? Indoor Built Environ. 2012; 21:381-391.

18. Seal DV, Clark RP. Electronic particle counting for evaluating the quality of air in operating theatres: a potential basis for standards? J Appl Bacteriol. 1990 68: 225-230.

19. Obbard J, Fang L. Airborne Concentrations of Bacteria in a Hospital Environment in Singapore. Water Air Soil Poll. 2003; 144: 333-341.

20. Nourmoradi H, Nikaeen M, Amin MM, Hatamzadeh M. An Investigation on Bio-aerosol Concentrations in the Different Wards of Hospitals of Isfahan University of Medical Sciences. J Isfahan Medical Sch. 2011; 29: 1028-1036. 